gives the formulae of the preparations commonly used in domestic or other fields. These are presented in functional groups, such as, for example, cleaning materials, agricultural pesticides, and paints.

The final section is an index of the names and addresses of manufacturers of products to whom reference can be made for more detail than can be given in the text. These are all American firms. The restriction of the manufacturers' names to those in North America limits the usefulness of this section for European readers but does not detract from the value of the main body of the book. In any case, it is more likely that this enormous volume will be bought for reference by the specialist or for a hospital library than by the general practising physician. The most assiduous reviewer could not hope to read every word of it, but the random samples taken and studied demonstrated the high order of accuracy and the meticulous cover given to the thousands of commercial products, chemicals, and mixtures which are included. Equally, none of importance, except those of very recent introduction, appears to have been missed.

T. S. SCOTT

First Annual Report (1968-1969) TUC Centenary Institute of Occupational Health in the London School of Hygiene and Tropical Medicine. (Pp. 20; 3 figs, 2 tables.) London: London School of Hygiene and Tropical Medicine. 1970.

When the head of one institute is invited to review the work of the head of another, a situation is produced which my mother would have described as 'piquant'. The colour of the covers of this report is an attractive blue, mid-way between the Oxford and Cambridge varieties, and it appropriately suggests nothing of a Conservative nature. The contents set out a record of the first full year's work of an institute created by the grafting of a new information and advisory service for industry on to Professor Schilling's original department in the London School of Hygiene. Horticultural experience gained in a secluded corner of Northumberland, combined with that of carrying out a similar manoeuvre many years ago in the Newcastle department, has taught us that grafts of both kinds need considerable cosetting in their early years. The first five are crucial.

The operation of a card index system of advice in a medical field is tricky. Administratively, it seems attractively convenient, but most enquirers from industry do not realize the full implications of what they are asking. The beginning of the answer to most of these questions is: 'It depends . . . .,' and one of the commonest things it depends upon is how the material is used. Boiling water in ordinary households is a lot more dangerous than uranium in the reactors of nuclear power stations. Statistics prove it! But to have earned in this new service over $£ 3,500$ in the first year at between $£ 500$ and $£ 600$ a job is good going - and most interesting.

On the teaching side the institute has started a new M.Sc. course in occupational medicine, and it is continuing its M.Sc. courses in occupational hygiene, for which there is an increasing demand.

The research of the institute needs no praise from the reviewer. Its excellence is matched only by its timely relevance, as is illustrated by the work on both asbestos workers and trawler fishermen. An important and sinister finding is the demonstration of under certification of mesothelioma as a cause of death in asbestos workers. Studies on the health of cotton and viscose rayon workers have also given interesting results. Shift systems, washing powder manufacture and the action of smoking on the 'ciliary escalator' are also being investigated.

A most interesting first report. We wish the new institute well.

$$
\text { R. C. BROWNE }
$$

\section{Books Received}

Water Pollution Control in Developing Countries. Report of a W.H.O. Expert Committee. (Pp. 38; 6s.) Geneva: W.H.O. 1969.

Catalogue of World Health Organization Publications. (Pp. 146; no price stated.) Geneva: W.H.O. 1969.

Lectures in Medicine. 2nd ed. By C. W. H. Havard. (Pp. 399; illustrated; 70s.) London: Staples Press. 1969. Nutritional Anaemia. Report of a W.H.O. Scientific Group. (Pp. 37; 8s.) Geneva: W.H.O. 1968.

Genetic Counselling. 3rd Report of the W.H.O. Committee on Human Genetics. (Pp. 23; 4s.) Geneva: W.H.O. 1969.

Sensitization to Drugs. Edited by S. Bole, C. Baker, and J. Tripod. Proceedings of the European Society for the Study of Drug Toxicity. Vol. X. (Pp. 256; illustrated; 134s.) Amsterdam: Excerpta Medica Foundation. 1969.

Measures of Adjustment of Rural Manpower to Industrial Work and Urban Areas. O.E.C.D. Social Affairs Division. (Pp. 111; 14s.) Paris: O.E.C.D. 1968.

The Hypertensive Vascular Crisis. An Experimental Study. By F. B. Byrom. (Pp. 131; 90 figs; 30s.) London: Heinemann Medical Books. 1969.

Official Services for Occupational Safety and Health. (Pp. 232; free) Geneva: I.L.O. 1968.

Community Water Supply. Report of a W.H.O. Expert Committee. (Pp. 23; 4s.) Geneva: W.H.O. 1969. Statistical Tables on the Health of the Army 1966. (Pp. 205; tables; no price stated.) London: Ministry of Defence. 1969.

Kinetic Handling. (Pp. 11; illustrated; 2s.) London: British Safety Council. 1969.

The Corner House Group Health Department. Report for the Year 1968. A. M. Coetzee, Director of Medical Services. (Pp. 24; 22 tables.) 1969.

Steel Castings Research and Trade Association. 16th Annual Report. Part II. Research Division. (Pp. 27.) Sheffield: Steel Castings Research and Trade Association. 1969.

Anglo American Corporation (Central Africa) Limited. Annual Report 1968. (Pp. 16; illustrated.) 1969.

Biochemistry of Mental Disorders. Report of a W.H.O. Scientific Group. (Pp. 40; 6s.) Geneva: W.H.O. 1969.

The Care of the Injured. 2nd ed. By P. A. Ring, (Pp. 166; 121 figs; 30s.) London and Edinburgh: Livingstone. 1969.

World Directory of Medical Schools. 1967 Supplement. (Pp. 39; 6s.) Geneva: W.H.O. 1969.

British Standards Institution. Annual Report 1968 to 1969. (Pp. 47; illustrated.) London: British Standards Institution. 1969.

Anglo American Corporation of South Africa Limited. Medical Consultants Report 1968. (Pp. 41; 1 table.) 1969. 